\title{
Polymyalgia rheumatica in the 2018-2020 guidelines. Part II: diagnosis of vasculitis
}

\author{
For citation: Bol', sustavy, pozvonočnik. 2021;11(1):1-16. doi: 10.22141/2224-1507.11.1.2021.226904
}

\begin{abstract}
The issue of improved diagnosis of both rheumatic diseases of the elderly and aortic diseases does not lose its relevance. In terms of aortic aneurysms, dissection and ruptures and their attended pathogenesis, both inflammation and structural wall damages may be detected with imaging methods whose role is vital. A number of international guidelines deal with the management of polymyalgia rheumatica, giant cell arteritis, or aortic aneurysms. Aortitis is associated with up to $40 \%$ of polymyalgia rheumatica's cases. The clinical suspicion of aortitis is based on the detection of blood pressure and pulse asymmetry, aortic regurgitation murmur, vascular bruits, as well as persistent polymyalgia rheumatica or inflammatory dorsalgia, pelvis or leg pain. In 2020, the positron emission tomography/computed tomography's use is approved by the Italian Society for Rheumatology for the diagnosis of vasculitis attended by polymyalgia rheumatica at the secondary healthcare level and by the European Headache Federation for the diagnosis of large vessel giant cell arteritis in the neurological practice. A review of the guideline by the European Association of Nuclear Medicine, the Society of Nuclear Medicine and Molecular Imaging, and the American Society of Nuclear Cardiology (2018) was performed in terms of positron emission tomography with fluorodesoxyglucose combined with computed tomography (angiography) imaging in large vessel vasculitis and polymyalgia rheumatica. It is further compared with the clinical guidelines, other guidelines by the societies of nuclear medicine and new scientific data. Both procedure and patient's preparation for examination are decribed. The criteria for assessing vasculitis proposed for either clinical practice or clinical studies are considered, as well as the factors influencing the test results and their interpretation (such as atherosclerosis, diabetes, age, body mass index, glucemia's and acute phase markers' levels). The guideline substantiates the benefit of both positron emission tomography's use and its combination with computed tomography to detect extracranial vasculitis, as well as the value of performing computed tomography-angiography at different stages of the disease. There is a need to strengthen evidence on both standard time of fluorodesoxyglucose exposure and the benefit of combining positron emission tomography with computed tomography-angiography, in particular for detection of vasculitis relapses. Finding a consensus for early test's performing is needed, as well as its score standardization, ensuring reimbursement and implementation of new imaging techniques for the cranial vessels. In the future, the evidence-based approach to managing vasculitis will be supplemented by teranostics.
\end{abstract}

Keywords: polymyalgia rheumatica; giant-cell arteritis; aortitis; imaging diagnostics; standards; review

By means of the contemporary methods of life-time diagnostics one cannot obtain evidence of GCA's mandatory presence in every PMR case, though the complete absence of vasculitis is far from certain either.

N.V. Bunchuk, 2010 [1, p. 131$]$

\section{Introduction}

The frequent combination of polymyalgia rheumatica (PMR) with vasculitis [1-5] is what accounts for its qualifier "polymyalgia arteritica", suggested by B. Hamrin 50 years ago. To the same extent, there is a hypothesis as to the PMR being the giant cell arteritis (GCA)'s manifestation [6]. Re- ferring to the issue of GCA manifested at various stages, starting with the PMR onset, and not always combined with the inflammatory lab markers, N.V. Bunchuk (2010) calls upon the clinical examination as a "determinant" vasculitis diagnostic tool, while the ultrasound of spinal and carotid arteries is not devoid of "relevance". He also noted that the magnetic resonance imaging (MRI), as well as the positron emission tomography (PET) combined with [18F] fluorodesoxyglucose (FDG), make for the optimal aortitis detection [1, c. 106-108, 130-132]. According to Cimmino M.A. et al. (2017), the imaging diagnostic tools, such as ultrasound, MRI, PET and computed tomography (CT), "have

C) 2021. The Authors. This is an open access article under the terms of the Creative Commons Attribution 4.0 International License, CC BY, which allows others to freely distribute the published article, with the obligatory reference to the authors of original works and original publication in this journal.

Для кореспонденції: Пузанова Ольга Геннадіївна, доктор медичних наук, доцент, професор кафедри внутрішніх та професійних хвороб, Приватний вищий навчальний заклад «Київський медичний університет», вул. Бориспільська, 2, м. Київ, 02099, Україна; e-mail: dr.puzanova@kmu.edu.ua; контактний тел.: +380-50-383-23-00.

For correspondence: Olha H. Puzanova, MD, PhD, Associate Professor, Professor at the Department of Internal and Occupational Diseases, Private Higher Educational Institution «Kyiv Medical University», Boryspilska st., 2, Kyiv, 02099, Ukraine; e-mail: dr.puzanova@kmu.edu.ua; contact phone: +380-50-383-23-00.

Full list of authors information is available at the end of the article. 
drastically modified our understanding of large vessel vasculitis (LVV)" and enabled us to explain the underlying causes of fever, weakness and other non-specific symptoms [7].

In Ukraine, the first attempts of LVV diagnostics by FDG-PET/CT were made at the All-Ukrainian Center of Radiosurgery by the Feofaniya Clinical Hospital and described by Smiyan S.I. et al. in 2014 [8]. In the Republic of Belarus, similar studies are performed at the State Institution "N. N. Alexandrov National Cancer Centre of Belarus".

The imaging diagnostic tools are detecting LVV in every one of three "clinically isolated PMR cases", this fact being proved by Camellino's D. et al. systemic review [9]. The "late GCA" attending PMR is often a subclinical arthritis: Liozon F. et al. detected it 6 times as often as in case of a classic GCA [10], the fact supporting Mayo Clinic's and other claims [4-5] of the latter diagnostic tools' decisive role.

In case of aortitis detection in combination with PMR, Cimmino M.A. et al. assume it may be interpreted as PMRassociated vasculitis, GCA, Takayasu's arteritis (TA) (with disease's onset before 50 years of age) or isolated aortitis (i.e. "single-organ vasculitis") [7]. It may also be associated with rheumatoid arthritis (RA), spondyloarthritis, IgG4-related disease, systemic lupus erythematosus, Beh et's disease (BD), Cogan's Syndrome and a range of other infections.

The GCA aortitis is associated with an elevated risk of aneurysm and acute aortic syndrome's developing due to thoracic aortic rupture or dissection [11-13]. The pathogenesis of ascending aorta's dilatation is attributed to the inflammation of its wall [14] and accelerated atherosclerosis developing on the background of glucocorticoid (GC) medication [15], there is also a high probability of Chlamidia pneumonia and anaerobic involvement [16-17]. Apart from atherosclerosis and arterial hypertension (AHT), the role of non-infectious diseases in the development of aortitis and its complications is not conclusively proven. For instance, the earlier discussed protective effect of diabetes mellitus (DM) against the aortic aneurism development, including the GCA-associated forms [12, 18], is attributed to the Metformin use [19].

The aortic diseases make up one of the topical healthcare issues [16, 19-22]. The aortic aneurysm diagnosis is made whenever its diameter increases by $>50 \%$, compared with initial level. The diameter of ascending aorta of up to $>60$ $\mathrm{mm}$ is considered risky due to a high probability of rupture, and thus an indication for surgery. During the recent 30 years, there was a steady growth of surgeries performed to remove the dissection and aneurysm of thoracic aorta. Out of 100, 000 cases presented annually, there were 4-10 cases of dissection and 5-10 of ascending aortic aneurysm; however, the true morbidity rate appears more significant due to an asymptomatic disease course up to the complications being developed $[17,23]$. In the UK, the issue of programmatic screening for the aneurysm of thoracic aorta in the GCA-afflicted males was raised in 2015 [12, 18]. Lariviere D. et al. referred to GCA as "the most common aortitis form, characterized by the long-term damage, wall thickening and distal lumen narrowing, namely in case of the de- scending aorta and subclavian arteries" [24]. According to Saeyeldin A. et al., the use of imaging methods "remains the only reliable approach to diagnostics and observation of thoracic aorta aneurysm" [25].

A range of publications delve into the analytical parameters and practical aspects of those tests used to detect GCA [4-5, 7, 12, 24, 26-28]. The CT and Magnetic Resonance Angiography (MRA) are used to detect the LVV's typical characteristic, namely circular thickening and wall contrast enhancement, stenosis, dilatation, vessel aneurysm. The MRA features of vasculitis also include vessel wall oedema; however, the latter is not considered pathognomonic [7]. The Color Doppler Ultrasound detects a dark hypoechogenous wall thickening in case of the present aortic branch inflammation, i.e. the "halo" symptom.

In terms of no optimal LVV imaging diagnostic method present, Cimmino M.A. et al. [7] consider inadequacy of ultrasound examination, MRI and PET to be their principal limitation, as far as the "golden standard" of histology was concerned. Villiger P.M. makes a similar remark as to the CT use [29]. In conclusion, the clinical decision-making retains its function of a key diagnostic component. For instance, the PET enables us to obtain a panoramic image of aorta and its branches, though its sensitivity goes down after three days of a high-dose GC-therapy, and even more significantly after ten days [30]. By the recent time, the PET use restricted our capacities of evaluation whenever the temporal and intracranical arteries and their condition was concerned; it was due to their size and intense FDG absorption by the brain. Due to a lack of standardization, there were controversies as to how the PET/CT results were to be interpreted. The study of Magnetic Resonance Angiography (MRA) as a diagnostic test for aortitis revealed its preeminence over the CT angiography (in addition to absent radiation loading), it might also be used at the $5^{\text {th }}$ day of GC-treatment: the MRA's positive prognostic value exceeded $89 \%$. The test has turned out a useful diagnostic tool for detection of temporal arteritis; it has a $93.6 \%$ sensitivity compared with biopsy. The PET/MRI was found to be more effective than $\mathrm{PET} / \mathrm{CT}$ in terms of vasculitis detection, whenever the wall thickness and contrast enhancement were chosen as parameters for T1-weighted images. As of 2017, the PubMed database had a similar number of reports specifying the MRI and PET uses for LVV diagnostics in clinical studies [7].

With the vascultis diagnostics updated, the methods are combined simultaneously and sequentially. L ffler C. et al. confirmed a high sensitivity of ultrasound examination while evaluating the status of subclavian and axillary arteries; however, when the aortitis, abdominal and leg artery inflammation were tackled, the sensitivity dropped down. With this issue in mind, they recommended PET/CT at further diagnostic stages. Their findings prove that the ultrasound diagnostics of GCA is $80 \%$ sensitive, while the Color Doppler Ultrasound matched with PET/CT increases the sensitivity by $16-20 \%$ [27].

Villiger P.M. claims that ultrasound examination, MRI and PET/CT are highly specific LVV diagnostic methods; however, neither one of these is validated for disease management (Table 1) [29]. 
The fact that PMR is included into the framework of systemic vasculitides, classification of LVV and GCA subtypes, exploration of their distractors, are subject to discussion and study. According to Lensen K.D. et al. [11], the clinical GCA range includes "classical" cranial, isolated giant vessel and mixed subtypes. In agreement with Dejaco C., Koster M.J. et al. [26] offer their own list of clinical differential-diagnostic PMR signs and symptoms and primary GCA subtypes (Table 2).

From Table 2, one can see that it is PMR which is barely discernible from large-vessel GCA. In both cases, the group of "very frequent" symptoms are made by fever, weight loss and proximal myalgia; the group of "frequent" ones - by acute phase markers. The remitting seronegative symmetrical synovitis with pitting edema which is typical of PMR is rarely observed with LVV; however, this vasculitis is often associated with an intermittent limping, pulse asymmetry at the legs and murmurs over the extracranial vessels. The chewing and visual impairments are neither characteristic for PMR nor for LVV (i.e., these risk factors of irreversible blindness and stroke are absent for both conditions); however, the headache, edema and tenderness of temporal area are observed with large-vessel vasculitis.
The Mayo clinic experts drew their conclusion on the importance of physical diagnostics for LVV: subjects at a high risk for vasculitis (i.e., all the PMR patients, especially with a persistent form) should get their arterial blood pressure measured at both hands, their heart and vessels auscultated, pulse at carotid and limb arteries evaluated. Whenever the arterial blood pressure or pulse asymmetry, diastolic murmur at the aortic valve or systolic murmur at the magistral arteries are present, one may reasonably suspect LVV and consider them an indication for the further instrumental imaging study [12, 26].

Although from an evidence-based medicine's perspective the risk factors of GCA complications should not be extrapolated directly on the PMR, they are nevertheless to be taken into account. It concerns, for instance, the key stroke predictor, namely in males, which is the "new" headache occurrence (temporal, occipital, frontal or generalized [31]), blindness predictors, i.e. jaw pain, dyslopia, anomaly of temporal arteries, and risk factors of aortic aneurism and death from its rupture, i.e. male gender, smoking, atherosclerosis and AHT [12]. It's worthy of note that in GCA's absence male gender turns out a risk factor of abdominal aortic aneurysm, while female gender - a risk factor of its rupture.

Table 1. Comparison of imaging diagnostic methods for detection of large vessel vasculitis [29]

\begin{tabular}{|c|c|c|c|}
\hline \multirow{2}{*}{ Parameter } & \multicolumn{3}{|c|}{ Diagnostic method } \\
\hline & Color Doppler Ultrasound & MRI & PET/CT \\
\hline Accessibility timeline & Immediate & During 24 hours & During several days \\
\hline Accessibility of arteries & Carotid, subclavian, arm arteries & $\begin{array}{l}\text { Extracranial, thoracic and } \\
\text { abdominal arteries }\end{array}$ & $\begin{array}{c}\text { Aorta and its branches (vascular } \\
\text { tree) }\end{array}$ \\
\hline Radiation loading & no & no & present \\
\hline Cost & low & high & very high \\
\hline Specificity & high & high & high \\
\hline Sensitivity & rather high & high & high \\
\hline Disease activity control & no validation & no validation & no validation \\
\hline
\end{tabular}

Note: MRI - magnetic resonance imaging; PET/CT - positron emission tomography matched with computed tomography.

Table 2. Differential-diagnostic signs and symptoms of polymyalgia rheumatica and subtypes of giant cell arteritis (by Koster M.J. et al. [26])

\begin{tabular}{|c|c|c|c|}
\hline Signs and symptoms & PMR & LVV-GCA & CGCA \\
\hline Headache & - & \pm & ++ \\
\hline Edema, tenderness along the temporal arteries & - & \pm & + \\
\hline Murmur over the extracranial vessels & - & ++ & - \\
\hline Pain of jaw or tongue at chewing & - & - & ++ \\
\hline Visual symptoms or complications & - & - & ++ \\
\hline Fever, weight loss & ++ & ++ & + \\
\hline Intermittent limping and/or pulse asymmetry & - & ++ & - \\
\hline Symptoms of polymyalgia rheumatica & ++ & ++ & + \\
\hline Acute phase markers & + & + & ++ \\
\hline Peripheral arthritis/RS3PE-syndrome & + & \pm & \pm \\
\hline
\end{tabular}

Note: PMR - polymyalgia rheumatica; GCA - giant cell arteritis; cGCA - cranial giant cell arteritis; LVV-GCA - Iarge-vessel giant cell arteritis; RS3PE - remitting seronegative symmetrical synovitis with pitting edema; ++ very frequent sign or symptom; + frequent sign or symptom; - uncharacteristic sign or symptom; \pm possibly occurring sign or symptom. 


\section{Modern recommendations on PMR, GCA and aortic diseases}

The past decade witnessed appearance of several international and country-specific recommendations on $P M R$ and GCA (Table 3). Besides the specialized societies, such as the European League against Rheumatism (EULAR) and American College of Rheumatology (ACR) [32-34], the UK-based societies, namely the British Society for Rheumatology (BSR) and the British Health Professionals in Rheumatology (BHPR), the French Study Group for Large Vessel Vasculitis (Groupe d'étude français des artérites des gros vaisseaux, GEFA) [37], the German Society of Rheumatology (Deutsche Gesellschaft für Rheumatologie, DGRh), the Austrian Society of Rheumatology and Rehabilitation (Österreichische Gesellschaft für Rheumatologie, ÖGR), the Swiss Society of Rheumatology (Schweizerische Gesellschaft für Rheumatologie, SGR) [38], the Italian Society of Reumatology (Società Italiana di Reumatologia, SIR) [39]. The interdisciplinary issue of large-vessel vasculitis management was raised by the guidelines of the Association of the Scientific Medical Societies in Germany (Arbeitsgemeinschaft der Wissenschaftlichen Medizinischen Fachgesellschaften, AWMF) [40] and the European Headache Federation (EHF) [31]. Furthermore, in 2020 there were 4 recommendations published, and in 2018 - there were three. There appeared guidelines by the European Society of Cardiology (ESC) [16] on diagnostic and management of aortic diseases and consensus statement on surgical pathology of the aorta from the Society for Cardiovascular Pathology and the Association for European Cardiovascular Pathology [20]. Besides the issue of acute aortic syndrome associated with thoracic aorta's pathology which is often at- tending the PMR, there is a range of recent international recommendations on screening, diagnostics and treatment of abdominal aortic aneurisms [19, 21], first and foremost in the elderly people. However, the risk group of PMR/GCA patients was never described. We should also mention the algorithms suggested by the Mayo Clinic experts and others in order to optimize the suspected LVV patient management and aortitis monitoring [12-13, 26].

\section{Recommendations by EANM/SNMMI/PIG/ ASNC (2018) on FDG-PET/CT(A) use to treat large-vessel vasculitides and PMR}

The PET was first introduced as an ancillary diagnostic test of vasculitis detection into the PMR management standards in 2020, while the first Italian clinical-practical guidelines were developed [39]. Its prototype - the DGRh/ GR/SGR guidelines (2018) on PMR management in Germany, Austria and Switzerland - considered the findings of a systemic review including 30 studies on imaging diagnostic tools to detect GCA; however, there were no recommendations on the PET use in clinical practice [38]. At the same time, the European Association of Nuclear Medicine (EANM) and the Society of Nuclear Medicine and Molecular Imaging (SNMMI), namely their task-force committees and PET Interest Group (PIG) developed their own guidelines on FDG-PET/CT use to detect large-vessel vasculitides and PMR, later endorsed by the American Society of Nuclear Cardiology (ASNC) [42]. Their target audience was made of radiologists and clinicians. The documents explored the issue of preparation for and performance of the above-mentioned procedure, as well as interpretation of its results in subjects with suspected LVV and PMR.

Table 3. The modern clinical recommendations on diagnostics and management of polymyalgia rheumatica and giant cell arteritis

\begin{tabular}{|c|c|c|}
\hline Source of recommendations & $\begin{array}{c}\text { Year of } \\
\text { publication }\end{array}$ & Patient groups \\
\hline \multirow{2}{*}{$\begin{array}{l}\text { European League against Rheumatism and American College of Rheumatology } \\
\text { [32-34] }\end{array}$} & 2012,2015 & PMR \\
\hline & 2018 & Large-vessel vasculitides \\
\hline European Society of Cardiology [16] & 2014 & Aortic diseases \\
\hline $\begin{array}{l}\text { Society for Cardiovascular Pathology and Association for European Cardiovascular } \\
\text { Pathology [20] }\end{array}$ & 2015 & $\begin{array}{l}\text { Surgical pathology of the } \\
\text { aorta (inflammatory) }\end{array}$ \\
\hline $\begin{array}{l}\text { French Study Group for Large Vessel Vasculitis (Groupe d'étude français des artérites } \\
\text { des gros vaisseaux) [37] }\end{array}$ & 2015 & GCA \\
\hline $\begin{array}{l}\text { German Society of Rheumatology (Deutsche Gesellschaft für Rheumatologie), } \\
\text { Austrian Society of Rheumatology and Rehabilitation (Österreichische Gesellschaft } \\
\text { für Rheumatologie), Swiss Society of Rheumatology (Schweizerische Gesellschaft für } \\
\text { Rheumatologie) and other medical societies [38] }\end{array}$ & 2018 & PMR \\
\hline $\begin{array}{l}\text { European Association of Nuclear Medicine (Cardiovascular, Inflammation \& Infection } \\
\text { Committees), Society of Nuclear Medicine and Molecular Imaging (Cardiovascular } \\
\text { Council), PET Interest Group and American Society of Nuclear Cardiology [42] }\end{array}$ & 2018 & $\begin{array}{l}\text { Large-vessel vasculitides } \\
\text { and PMR }\end{array}$ \\
\hline $\begin{array}{l}\text { British Society for Rheumatology and British Health Professionals in Rheumatology } \\
\text { [35-36] }\end{array}$ & 2010, 2020 & GCA \\
\hline Italian Society of Reumatology (Società Italiana di Reumatologia) [39] & 2020 & PMR \\
\hline $\begin{array}{l}\text { Association of the Scientific Medical Societies in Germany (Arbeitsgemeinschaft der } \\
\text { Wissenschaftlichen Medizinischen Fachgesellschaften) [40] }\end{array}$ & 2020 & GCA \\
\hline European Headache Federation [31] & 2020 & GCA \\
\hline
\end{tabular}

Notes: GCA - giant cell arteritis; PMR - polymyalgia rheumatica; PET - positron emission tomography. 
We have made a content-analysis of the document, having compared its clauses with the modern guidelines on PMR, GCA and aortic diseases (Table 3) and the earlierdeveloped guidelines by the nuclear medicine societies on FDG-PET/CT use to detect tumors, infections, atherosclerosis, sarcoidosis [43-48]. Furthermore, using the Google search engine, we've put in the search terms of «polymyalgia rheumatica» and "positron emission tomography», and using the "link-crawling" method, we've performed the search of articles published in the peer-reviewed journals in 2018-2020, as well as the content analysis of their titles and abstracts. As a result, we selected and explored 87 publications, including 28 of those published after 2018 and absent from the recommendations under scrutiny.

It is well-known that a hybrid method of FDG-PET/ CT produces the images reflecting the activeness of glucose turnover (FDG uptake degree) and structural alterations occurring as a result of one study being performed on one machine. Having indicated a strong association between the degree of FDG uptake by the vessel wall and degree of its infiltration by the microphages, as well as a preponderant use of this radiopharmaceutical drug for imaging of atherosclerotic plaques, Hyafil F. et al. refer to the FDG-PET as "a well-credited method of diagnostics and monitoring of inflammatory activity" under atherosclerosis [49]. During the recent years, the researchers are eagerly exploring the FDG-PET/CT diagnostic, monitoring and prognostication uses as far as the inflammatory intestinal diseases, IgG4 diseases, polycystic kidney disease (PKD), HIV-related diseases, infections of prosthetic joint infection (PJI) etc.

The FDG-PET/CT's accuracy in detecting the articular structure and periarticular tissue inflammations is vitally important for differential PMR diagnostics within a range of late-onset rheumatic diseases associated with infections and tumors [50-54]. However, the 2020 Italian guidelines [39], as well as their prototypes [33, 38], opt for the clinical-anamnestic method and clinical judgment: "The real demand for extra tests should be determined by the attending healthcare provider in order to avoid the excessing screenings, which are less beneficial to the patient and incur higher costs" [42].

Discussing the peripheral arthritis as an "atypical" sign requiring rheumatologist's consultations and being a risk factor of PMR's paraneoplastic character whenever $\geq 6$ joints are involved [41], we should point out that the engagement of knee, radiocarpal and sternoclavicular joints [1, 38] turned out to be almost inherent for the disease: the frequency of gonitis being detected by PET was $50 \%$ [55]. As to the periarticular FDG uptake, the PMR is most commonly characterized by the shoulder girth localization (Malik D. et al., 2020) [56].

In this connection, the Italian guidance on PMR [39] recommends using FDG-PET/CT as a highly accurate diagnostic test (evidence base $-2 \mathrm{~B}$, i.e. non-randomized trials), exclusively intended for the vasculitis detection at the specialized healthcare stage (evidence level - 5D, i.e. expert opinion). It corresponds to other recommendations of 2018-2020 [31, 34, 36, 40] on suspected GCA of large vessels as a primary indication for this test. For instance, the EULAR (2018) does not recommend CT or PET for the evaluation of cranial arteries' inflammation; however, it endorses its use (along with the ultrasound examination and MRI) "to detect the wall inflammation and/or alterations of extracranial arterial lumen, corroborating the LVV-GCA diagnosis" [34]. The UK rheumatologists (BSR, 2020) opine that "in order to evaluate the damage of aorta and its proximal branches one may use FDG-PET, MRI- or CT-angiography, as well as color Doppler ultrasound examination of axillary arteries" [36]. The German AWMF association gives two recommendations (2020): With predominant engagement of extracranial vessels suspected we recommend MRI/MRI-angiography, PET/CT or PET and In order to perform (additional) evaluation of aortic damage under a predominantly cranial GCA, one may use MRI, CT or PET/CT [40]. Finally, the EFH (2020) recommends the European neurologists to use only FDG-PET/ CT [31] if the extracranial GCA is suspected, in line with the Italian guidelines.

As to the results of the PET/CT use to detect the PMR, the frequency of LVV-GCA detection reaches 20-30\% with an "isolated" PMR and $40 \%$ with PMR marked by vasculitis [9, 57-58]. This fact has a significant influence on the prognosis and therapeutic practice. Some authors claim that with a strong clinical GCA suspicion "one should not be dissuaded from PET/CT use" even by the negative biopsy results (i.e. absence of arteritis with predominant mononuclear proliferation or granulomatous inflammation with giant multinuclear cells present), ultrasound examination (i.e. absence of "halo" symptom) or MRI (i.e. absence of edema and aortic wall thickening) [59-60]. In this connection, the multicenter trial by Prieto-Peña D. et al. [61] claiming that the best predictors of FDG-PET/CT outcomes (i.e. LVV detection) with a "classic" PMR are the inflammatory pain in the lumbar spine (OR 4.7; $95 \%$ CI 1.03-21.5), pelvic area (OR $4.9 ; 95 \%$ CI 1.50-16.53) and inflammatory pain of legs (OR 8.8; $95 \%$ CI 1.7-46.3) turned out to be the most interesting. In this case, the researchers were using 2012 EULAR/ACR classification criteria [29], they tested 84 PMR patients (mean age -71.4 years, percentage of women $-60.7 \%$ ). The key indication was persistent PMR; the frequency of positive outcomes $-60.7 \%$.

Thus, using FDG-PET/CT for patients with a "classic" PMR, one may detect arthritis or periarthritis of knee joints in every second case, and in every third one - the inflammation of aorta and its proximal branches (especially with inflammatory pain present in the back, pelvis, legs). With persistent PMR signs, the large-vessel vasculitis was detected in most cases.

With GCA undetected, the PET/CT's diagnostic role is also great: most commonly its findings are used to detect other causes of systemic inflammation in the elderly subjects, namely infections and malignant tumors (this method was originally developed for this purpose specifically). De B.H. et al. suggest to use its synergistic value for optimal diagnostics, monitoring of disease activity and assessment of damage progressing with large-vessel vasculitis [60], earlier claimed by Einspieler I. et al. for PET/MRI [59, 62]. 
Nevertheless, the 2020 Italian guidelines were the first to outline the prospects of classical hybrid test use in PMR's case, point out "the uncertain role of imaging methods" both for diagnostics and treatment monitoring purposes [39]. This claim was based on the conclusions of EANM/ SNMMI/PIG/ASNC (2018), presented in Table 4 as a "consensus statement" on FDG-PET/CT(A) use to detect LVV and PMR [42]. By that time, the societies published their own protocols on FDG-PET use to diagnose the infections (2013) [43], tumors (2015) [44] and heart conditions (2013) [45], namely sarcoidosis (2017) [46]. They also raised an issue of standard's being developed for LVV and PMR detection. The key FDG-PET/CT(A) limitation was, by the expert opinion, "an absence of international consensus on vasculitis detection and/or PMR detection based on the intensity and pattern of FDG uptake". The factor impeding the FDG-PET findings' interpretation was "atherosclerosis activity" [42].

As may be seen from Table 4, most statements by EANM/ SNMMI/PIG/ASNC (2018) have the II level of evidence (i.e. primary studies, though not meta-analyses). The most well-grounded statement is the one on "possible detection of structural vessel alterations and vasculitis complications by means of CT-angiorgraphy" (class of evidence - II, power of evidence - A). The statement on the high efficacy of $F D G-P E T$ in LVV and PMR detection is based on the same level of evidence (II-B) as the 2020 Italian recommendation on FDG-PET/CT. the weak evidence and expert opinion stand behind: the duration of FDG exposition of 60 minutes; the option of GC suspension or FDG-PET use during the first three days after therapy; the FDG-PET/CT(A) may be effective in appraising the treatment response.

To the same extent as the 2018-2020 recommendations by the European rheumatologic societies [38-39, 41], the guidelines by the nuclear medicine societies reflect the importance of consensus approach for creating the medical standards under the lack of evidence.

The guidelines by the nuclear medicine societies [42] claim that 6 hours before the FDG injection the patient should consume only water, 24 hours before the FDG injec-

Table 4. The consensus recommendations and clauses by EANM/SNMMI/PIG/ASNC (2018) on FDG-PET/CT(A) use to detect polymyalgia rheumatica and large-vessel-vasculitis [42]

\begin{tabular}{|c|c|}
\hline Consensus recommendations & $\begin{array}{l}\text { Gradation of evidence } \\
\text { and recommendations }\end{array}$ \\
\hline $\begin{array}{l}\text { The patient should abstain from food during at least } 6 \text { hours before FDG injection; } \\
\text { however, use of low-calorie drinks is allowed }\end{array}$ & II, B \\
\hline $\begin{array}{l}\text { The normal glucose blood level is desirable, preferably at the level of }<7 \mathrm{mmol} / \mathrm{L} \\
(126 \mathrm{mg} / \mathrm{dL})\end{array}$ & II, B \\
\hline $\begin{array}{l}\text { With no high risk of ischemic complications developing (as in the case of GCA with } \\
\text { cranial vessels' engaging), one recommends the complete cessation or suspension of GC } \\
\text { therapy before PET. FDG-PET may be an alternative option during the first three days of GC } \\
\text { treatment }\end{array}$ & III, B \\
\hline $\begin{array}{l}\text { In between FDG and scanning performed one should keep at least a } 60 \text {-minute interval. } \\
\text { This is the time required for the adequate biodistribution }\end{array}$ & III, B \\
\hline $\begin{array}{l}\text { One recommends the following gradation of FDG uptake: } 0 \text { - no uptake (i.e. } \leq \text { mediastinal } \\
\text { uptake), } 1 \text { - low uptake (< hepatic uptake), } 2 \text { - moderate uptake (=hepatic uptake), } 3 \\
\text { - high (>hepatic uptake); at } 2 \text {, the test is considered probably positive, at } 3 \text {, the test is } \\
\text { considered positive as to an active LVV present }\end{array}$ & II, B \\
\hline $\begin{array}{l}\text { One should detect and evaluate the typical pattern of FDG uptake by the shoulder and } \\
\text { pelvic joints, intervertebral joints of cervical and lumbar spine, knee joints }\end{array}$ & II, B \\
\hline $\begin{array}{l}\text { A good benchmark of vascular inflammation is normalization of FDG uptake by the arterial } \\
\text { wall up to the background activity of venous blood pool }\end{array}$ & II, B \\
\hline $\begin{array}{l}\text { The widely recognized method of evaluating arterial vessel inflammation is comparison } \\
\text { with FDG hepatic uptake }\end{array}$ & II, B \\
\hline Consensus statements & $\begin{array}{l}\text { Gradation of evidence } \\
\text { and recommendations }\end{array}$ \\
\hline Evidence proves a high diagnostic efficacy of FDG-PET in the LVV and PMR detection & II, B \\
\hline $\begin{array}{l}\text { Further studies are necessary in order to select the most clinically significant and } \\
\text { reproducible criteria of LVV detection by FDG-PET, as well as for the clinical testing of FDG- } \\
\text { PET scanning results while managing patients with a suspected LVV }\end{array}$ & - \\
\hline To diagnose LVV, the CT(A) and FDG-PET are mutually contributing & III, B \\
\hline $\begin{array}{l}\text { The added value of CT(A) method consists in possible detection of structural vessel } \\
\text { alterations and vasculitis complications }\end{array}$ & II, A \\
\hline $\begin{array}{l}\text { The FDG-PET/CT(A) may be effective in appraising the treatment response by means of } \\
\text { functional metabolic disorder and structural vessel alteration monitoring; however, this } \\
\text { fact is to be proven by further prospective trials }\end{array}$ & III, C \\
\hline
\end{tabular}

Notes: EANM - European Association of Nuclear Medicine; SNMMI - Society of Nuclear Medicine and Molecular Imaging; PIG - PET Interest Group; ASNC - American Society of Nuclear Cardiology; PMR - polymyalgia rheumatica; CT(A) - computed tomographyangiography; PET - positron emission tomography; FDG - fluorodesoxyglucose; FDG-PET - fluorodesoxyglucose positron emission tomography; FDG-PET/CT(A) - fluorodesoxyglucose positron emission tomography/computed tomography-angiography; GC glucocorticoids; LVV - large-vessel vasculitis. 
tion one should abstain from rigorous physical exercising. Taking into account the previously published guidelines [4445], in case of fever with an unclear genesis and suspected heart condition one should keep a zero-carb diet with a high fat rate during 12-24 before the examination, fast for 12-18 hours and/or get heparin IV 15 minutes before the FDG injection. Before the scanning, the patient should empty his/ her bladder. In order to reduce the FDG uptake by muscles and brown fat, the examination is held in a warm (20-22 C) space. With the same purpose in mind, the patient is given a $20 \mathrm{mg}$ dose of Propranolol an hour before the radiopharmaceutical drug injection.

Upon account of weak evidence of glycemic effect on the FDG uptake by the inflammation-afflicted tissues, the rate of $<7 \mathrm{mmol} / \mathrm{L}$ is considered preferable: at a higher glucose blood level, the FDG bioavailability is compromised (it is faster reaching the organs of high insulin receptor density, namely the myocardium and skeletal muscles), deteriorating the scan quality. Overall one should aim for the most significant possible reduction of glycaemia level [42]. This claim is based on the 2014 Bucerius J. et al.'s prospective study of 195 patients, ascertaining the negative correlation between the fasting glycaemia level prior to PET and the FDG uptake by the inflamed aortic wall and carotid arteries. The optimal duration of FDG exposure lasted 2.5 hours while the FDG dose was found to be not that important [63].

The need for time standardization of FDG-PET/CT proto$c o l$ is also pointed out by the guidelines under scrutiny; they observe that in most clinical studies of the test intended to detect large-vessel vasculitides, the FDG exposure lasted 60 minutes [42]. In 2016, the EANM recommended keeping a 2-hour interval in between the FDG injection and PET scanning to detect atherosclerosis [47]. If the standard 60-minute exposure is doubled, the patient lying supine, and bigger imaging matrices used, the minor vessels of head and neck are better visible, according to Huet P. et al. [64].

Alternative approach was suggested by EHF (2020) to the neurologists in charge of GCA treatment. Commenting on the technical difficulties of FDG-PET interpretation in the cranial GCA cases, they recommended MRI with a 3-7 $T$ magnetic field induction in order to get images of superficial temporal and extracranial arteries. The experimental studies also use such promising methods as photoacoustic imaging and optical coherent tomography of superficial temporal arteries [30].

With no recommendations on FDG-PET/CT use to detect GCA/PMR at the moment of those guidelines' publication, they suggested total body scanning (feet included), with an optimal patient supine positioning, arms at his/ her sides (for the PMR patients find it difficult to keep their arms raised over their heads). The scanning direction is craniocaudal-wise. In order to receive a $3 \mathrm{D}$ image, one should take $2-3$ minutes. The FDG dose is $2-3 \mathrm{mBq} / \mathrm{kg}$ or $0.054-0.081 \mathrm{mCi} / \mathrm{kg}$ (depending on the camera type). The standard FDG exposure is 60 minutes.

One should point out that the PET/CT use involves FDG-PET combination with a non-contrast low-dose CT in order to correct the signal attenuation and to provide the anatomic referencing. The CT angiography with contrast enhancement is called an alternative option, "used in compliance with a local or national protocol" with account being taken of lacking evidence in favor of its routine use to detect GCA [42].

Our analysis of the reference sources demonstrated that the FDG distribution-affecting factors, relevant for the LVV-afflicted arterial wall, were described only after the EANM/SNMMI/PIG/ASNC guidelines were published. The 2019 Rosenblum J.S. et al.'s study of coupled PET scans of $69 \mathrm{LVV}$ patients showed that the FDG uptake by the arterial wall is most affected by age, body mass index (BMI) and $C$-reactive protein rate both after 60 and 120 minutes following the FDG injection, while the creatinine clearance test takes effect only after an hour [65].

Furthermore, the interpretation of FDG-PET/CT results in the elderly PMR patients is affected by the presence of vascular inflammation attending atherosclerosis, diabetes mellitus and GC medication.

The specific features of FDG uptake in patients with atherosclerosis are widely-known and well-described ("patchy-pattern" lesions being referred to as "classic" ones). The nuclear medicine societies take them into account $[47,49]$. In this aspect, the progress may be associated with various functional profiles of vessel wall macrophage detection in case of ischemic heart disease and GCA [66].

The aortic atherosclerosis features on the list of inflammatory diseases. In 2015, the consensus of the Society for Cardiovascular Pathology and the Association for European Cardiovascular Pathology confirmed a more significant frequency of pronounced atherosclerosis detection in the abdominal aorta than in the thoracic one; it is detected in 80 and $10 \%$ of the reviewed segments respectively [20]. The nuclear medicine societies draw attention to the interpretation of FDG uptake by the iliofemoral arterial segment per se, i.e. the preferred atherosclerosis localization. In LVV case, the PET/CT scans reveal a typical smooth linear picture of aortic lesions, subclavian, carotid, vertebral arterial lesions, and in Takayasu's arteritis (TA)'s case, also pulmonary arterial lesions [42].

The GC use is affecting the FDG uptake by the inflammation-afflicted tissues and liver, which is why it is considered an impeding factor. In case of PMR-attended vasculitis, the "window of diagnostic opportunity" is defined as 3-day period of GC therapy, according to the EANM/SNMMI/ PIG/ASNC recommendations. There is a probability of the pathological FDG uptake recovery and false-negative result frequency reduction after a short-term GC cessation, only possible in case of a low ischemic complication risk [42]. The data of 5-day PET/MRI diagnostic window [7] require further scrutiny, as well as a GC cessation option reserved for the imaging tests intended to confirm the LVV suspicion.

The frequency of diabetes and its burden in subjects with PMR/LVV on a long-term GC medication were first explored by Lai L. et al. in their metaanalysis of 2018 [67]. The cumulative GC doses were 5.6 and 8.2 during 4.4 and 6.4 years of their use respectively. As a result, the diabetes morbidity in the PMR and GCA patients turned out to be higher than that of the age- and gender-matched healthy 
population members: the cumulative morbidity rate was $6 \%$ in PMR case and $13 \%$ in GCA case, the expected morbidity rate being calculated as $4.8 \%$ in PMR case and $7 \%$ in GCA case. The GCA-attending de novo diabetes development risk turned out to be twice as high as the PMR-attending one. It is worthy of note that the participants had an advanced mean age (71.6 and 74.9 years in PMR case and in GCA case, respectively); the primary evidence were obtained primarily from Europe during the time when the diabetes prevalence was lower than today, and thus heterogeneous; various GC medications were being used; there is a lack of data on other diabetes risk factors, including the AHT and atherosclerosis medications. Relying on the metaanalysis findings and the fact that the diabetes development risk is especially high during the first year of GC therapy and growing by $5 \%$ with every gram of Prednisolone taken, Lai L. et al. suggested a higher-than-usual share of GC-induced diabetes within the range of GCA-associated de novo diabetes. They also point out that it is impossible to distinguish the disease effect and the treatment effect [67]: as a systemic inflammation induces the insulin resistance, both PMR and GCA may increase the diabetes risk.

As we have demonstrated earlier [13], the risk of diabetes developing in the GCA patients was elevated by 5 to 70 $\%$, according to various estimations. With a high-dose GC treatment, it exceeds the risk of all other complications, whenever elevated by 3-8 times.

The above-mentioned facts may restrict the FDG-PET use in order to control vasculitis activity in the PMR patients on GC medication, especially at a daily dose of $>30 \mathrm{mg}$, the diabetes patients or subjects with other risk factor of its development. For this purpose, this test is not validated as yet $[29,42]$, and the progress may be associated with the PET tracer use, FDG alternatives, suggested for atherosclerosis [49].

Preparing the patient for CT(A) and obtaining scans, one is advised to follow the guidelines by the American College of Radiology, the North American Society for Cardiovascular Imaging, the Society of Interventional Radiology, the Society for Pediatric Radiology (ACR/NASCI/ SIR/SPR, 2016) [48]. The patient's lying supine, with his/ her arms at the sides, for the express purpose of PET/CT scanning (in other cases, the arms should be raised over the patient's head, position which may be problematic for the PMR patients). the scanning may be performed on the entire aorta and its branches, including neck, arm vessels, internal organs, renal, pelvic and femoral vessels. The 80-150 $\mathrm{ml}$ contrast agent (a low-, or isosmolar one containing 300$40 \mathrm{mg} / \mathrm{ml}$ ) should be injected into the antecubital vein at a speed of 3.0-5.0 ml/sec. The optimal arterial scanning stage implies the bolus injection of contrast agent, scanning in the craniocaudal direction, prophylaxis of aortic movement-related artifacts, as well as synchronization with electrocardiography (EKG). As to the specific machine CT modes, one recommends referring for customized recommendations, as producers' parameters and protocols may vary and depend on the camera types [42].

It's worthy of note that in 2011-2016 a number of societies [16, 44, 48, 68] recommended the multispiral CT,
EKG synchronization, automated contrast agent injection, individualized calculation of dosage considering the patient's weight, BMI and creatinine clearance, as well as $\mathrm{CT}$-scan reconstruction in the $1 \mathrm{~mm}$ sections, allowing the researchers to obtain 3D images. The CT angiography is aimed at diagnostics and localization of primary vasculopathies, including vasculitides, infections and degenerative diseases [48].

The 2018 EANM/SNMMI/PIG/ASNC guidelines point out the CT angiography's benefit at various stages of $L V V$ development. With active vasculitis, it helps evaluating the vessel lumen and detect the acute complications of critical stenosis; with chronic disease forms, it serves as the MRI alternative for aneurism detection and assists the percutaneous and surgical intervention planning. With no atherosclerosis, the CT angiography poses no difficulties as an LVV diagnostic tool; vasculitis has its distractors in the overall thickening of the wall, and a "focused" presentation of atherosclerotic plaques. At the same time, the evidence base of PET/CT with contrast enhancement remains weak [42].

A typical CT-angiographic sign of aortitis was singled out by Agard C. et al., Prieto-Gonz lez S. et al. (2012). It is a circular 2-3 mm thickening of aortic wall with an adventitial and periadventitial contrast enhancement [12, 26, 69-70]. There are suggestions of an association existing between an extent of contrast enhancement and aortic wall inflammation activity, as the studies pinpoint its attenuation with GC treatment in the GCA patients; however, the aortic wall thickening remained unchanged [71].

The guidelines under scrutiny suggest the following definition of LVV-related notions: aortic wall thickening of 2-2.9 mm being "insignificant", 3-3.9 mm - "moderate", $\geq 4 \mathrm{~mm}$ - "significant" [42]. It is the thickness of $>4 \mathrm{~mm}$ which is mentioned as one of the inflammatory atherosclerotic aneurism criteria by the Society for Cardiovascular Pathology and the Association for European Cardiovascular Pathology [20].

As it is obvious from Table 4, both FDG-PET and CT angiography are recognized as valuable in the LVV detection by the EANM/SNMMI/PIG/ASNC (class of evidence 2). The efficacy of FDG-PET/CT(A) was referred to as weak, despite the CT angiography's benefit [42]: while the FDG uptake is intensified both with vasculitis and with atherosclerosis, the MSCT angiography has a great informative value for localization, prevalence and stages of pathological process, helps detecting the emergency condition during the initial examination, controlling aneurism and dissection development. This fact is especially important in view of the inflammation being far from an exclusive determinant of vascular dilatations progressing due to the GCA.

The FDG-PET/CT findings' interpretation. Among the unified, reproducible and easy-to-use vasculitis criteria used to evaluate the PMR and GCA patient condition, the guidelines under scrutiny mention the visual analogue scale (VAS), pattern and extent of the FDG uptake, total vascular score (TVS), semi-quantitative characteristics, standardized uptake value (SUV), ratio of vessel wall FDG uptake to hepatic FDG uptake, pulmonary FDG uptake, blood FDG uptake. Fewer criteria are suggested for Takayasu's arteritis 
(TA): VAS, semi-quantitative characteristics, extent of the FDG uptake, SUV, ratio of vessel wall FDG uptake to blood FDG uptake [42].

The evidence obtained during the 15 recent years supports the reliance on 0-3 gradation VAS comparing the vascular FDG uptake with hepatic FDG uptake: 0 - no uptake (i.e. $\leq$ mediastinal uptake), 1 - low uptake ( $<$ hepatic uptake), 2 - middle uptake (= hepatic uptake), 3 - high uptake $(>$ hepatic uptake); at the level 2, test is considered probably positive; at the level 3 , test is considered positive as to active LVV [12, 42, 72-73]. The evaluation of vascular inflammation using this parameter is considered "universally accepted". Furthermore, the evidence of II-B class supports such a benchmark as normalization of FDG uptake to the background activity of venous blood pool (Table 4 ).

The TVS parameter is found to be negative ( 0 points) or positive at the seven segments (thoracic and abdominal aorta, subclavian, axillary, carotid, iliac and femoral arteries) by means of a semi-quantitative uptake evaluation (1 point - minimum uptake, 2 points - significantly elevated, 3 points - very significant). The TVS calculation may be performed at the scale from 0 to 21 points, where 0 corresponds to zero FDG uptake at all seven vascular segments, 21 - to maximum uptake (3 points at each segment) [42]. It's worth mentioning that in 2020 Malik D. et al. revealed a strong correlation between the TVS values and erythrocyte sedimentation rate in the PMR patients with the PET-confirmed vasculitis. In a group of 106 examined patients, the FDG uptake was observed at $13.18 \pm 3.4$ vascular segments (from 3 to 19) on average; the greatest one (by SUVmax) being ascertained at the thoracic and abdominal aortas, and subclavian arteries [56].

Taking into account the frequent PMR and LVV correlation, the visual evaluation of vascular uptake and TVS calculation should be supported by the description of a typical FDG musculoskeletal uptake pattern, where synovial lining of shoulder, hip and knee joints, tendons of supraspinous muscle and biceps muscle of arm, bursas (subacromial-subdeltoid, ischial and trochanteric bursas), as well as the interspinal spaces of cervical and lumbar spine [42]. The uptake is evaluated by the scale from 0 to 3 points $[57,74]$.

The standardized criteria of LVV and PMR-associated FDG-PET/CT(A) findings' interpretation, suggested by the EANM/SNMMI/PIG/ASNC for the clinical practice and clinical trials, are presented in Table 5.

It's interesting to point out that the use of $S U V$ and $T B R$ (target-to-background ratio, i.e. vascular FDG uptake to the hepatic or blood uptake ratio) values for the primary LVV diagnostics was not recommended for the clinical practice (Table 5). However, there were suggestions of their use for the evaluation of treatment effect and relapse detection [42, 75]. For the vasculitis detection, in their later study, Rosenblum J.S. et al. ascertained the most significant informative value of the TBR taken 2 hours after the FDG injection [65]. Those data are equally relevant for the analytical PET evaluations and standardization of PMR and LVV trial protocols.

The target-to-blood pool ratio (vascular FDG uptake to the blood uptake ratio) is also recommended exclusively for the trials [42] - based on the EANM's advice to use it for the evaluation of atherosclerosis-originating vessel wall inflammation [47] as well as for a range of GCA-related findings [76-77].

As it was mentioned earlier, in order to evaluate the extent of arteritis intensity, one should consider normalization of the FDG uptake by the arterial wall as opposed to the venae cavae [77]. However, the inflammation is more commonly evaluated by means of target-to-liver ratio (i.e. hepatic FDG uptake) $[12,72,77]$. The activity of FDG uptake by the circulating blood flow is affected by several factors, such as glycemic level and creatinine clearance [78-80]. The aggregate value of those effects reflects on the clinical trial findings.

The repeat PET/CT tests and semi-quantitative evaluation of their results should be performed in compliance with the same protocol as the primary ones. In order to evaluate the treatment response, one should compare the scans made before and after the treatment. On detecting the slightest FDG uptake in the previously damaged segment, one should consider the residual inflammation [42].

Overall, the recommendations under scrutiny demonstrate $a$ high diagnostic accuracy of PET and PET/CT tools in LVV detection [42]. It was confirmed by Lee Y.H. et al. [81] and Soussan M. et al. (2015) [73] in their metaanalyses; it also turns out to be higher with GCA than with Takayasu's arteritis (TA). This fact is associated with a shorter term of GC use by the elderly patients at the moment of study. Some authors claim $[51,72,82-83]$ that this hybrid test's sensitivity is 64 to $92.3 \%$, while its specificity is 76.5 to $100 \%$. The above-mentioned discrepancies may be attributed to different criteria being in use for PMR and vasculitis diagnostics, absence of clear PET-criteria of LVV detection, group heterogeneity, rareness of comparison with the "gold standard" and influence of the high GC doses, which are prescribed right after the GCA is suspected [12, 42].

It is the corroboration of PMR-attending aortitis which is referred to as the most complicated diagnostic issue, while the radiopharmaceutical drug's uptake (i.e. PET-test) is often "the only mode" enabling the large-vessel inflammation detection.

It's vital to observe that the PET/CT- angiography's effectiveness is considered "uncertain" [42].

Monitoring the GC and immunosuppression drug effect by PET/CT. The studies on PET-control of the LVV treatment bring controversial results and were performed in the heterogeneous cohorts. In the guidelines under scrutiny, there is one prospective study on GC treatment control and another on Methotrexate (MTX) (both used to treat GCA). They point out the absent PET control studies of biotherapy effectiveness, including Tocilizumab's effect in GCA treatment [42]. With GCA, there is a long-term retention of lymphocyte infiltration in the temporal arteries' biopsy samples (up to a year following the high GC dose treatment) [12]. This phenomenon correlates with the detection of an increased vascular FDG uptake after 6 months; at which time it is not considered a sign of vasculitis. As far as PMR is concerned, the PET control of vasculitits hasn't been studied properly; the optimum follow-up period of GC treatment, 
which is necessary for confirmation of its effect, is unknown. In this connection, the experts recommend investigating the FDG-PET/MRI capacities [42], as this method has a lower radiation loading [62].

The prospects of further LVV and PMR imaging diagnostic studies are mentioned in the conclusions of the EANM/SNMMI/PIG/ASNC studies.

From the clinical point of view, the suggestions are: to outline indications and frequency of FDG-PET/CT(A) use for PMR and LVV diagnostics and monitoring; to include the parameters of imaging tests into the diagnostic criteria; to develop the clinical recommendations of FDG-PET/ CT(A) use for PMR and LVV (based on the new randomized trials and extant malignant tumor manual [44]); to continue studying the GC effect on the FDG uptake and to reach a consensus on the earliest possible PET use before the GC treatment initiation; to rule out the conditions which cause myocardial injuries in LVV patients, including the elevated cardiovascular risk associated with vascultis GC treatment.

Along with the evidence-based approach to PMR and LVV management, one should develop theragnostics, i.e. to detect a diagnostic test enabling identification of patient subgroups, particularly susceptible to positive/negative treatment effects. Those subgroups are found within a larger pool of specific nosologies. In GCA, though not in PMR case [13, 38-41], the PET-tracer is the radioisotope-labeled Tocilizumab [42].

In terms of organization, one should recover FDG-PET/ CT(A) costs at every stage of LVV and PMR treatment and develop e-training of imaging test interpretation [42].

The methodological aspects suggest standardization of FDG-PET/CT(A) use for PMR and LVV (relevant whenever the data from various medical centers are compiled within an universal database); evaluating the FDG-PET and CT efficacy as individual and hybrid standardized tests diagnosing those diseases. One should clearly define the LVVassociated notions and reach consensus on their quantitative appraisal. One should study the effect of long-term (90-120 minute) FDG exposure and FDG-PET/CT modifications (namely, dual-time-point imaging, DTPI) on the quality of hepatic failure patients' scans. The issue of cranial imaging and reconstruction methods being developed remains quite topical, as they enable a better description of temporal arteries and GCA subtypes [42]. In this connection, there are interesting findings on possible uses of FDG-PET/CT for diagnostics of tumors and head/neck vasculitides, namely cranial GCA in the GAP study [79-81].

The technical tasks include: optimization of hybrid imaging methods being used for monitoring of LVV-associated residual vessel wall modifications; optimization of MSCT and computed methods to distinguish between LVV and

Table 5. Interpretation criteria of fluorodesoxyglucose positron emission tomography/computed tomography-angiography findings on large-vessel vasculitides (by [42])

\begin{tabular}{|c|c|}
\hline Criterion & Description \\
\hline \multicolumn{2}{|c|}{ For clinical practice } \\
\hline Visual LVV evaluation (GCA and Takayasu's arteritis) & $\begin{array}{l}\text { Level 0: no FDG vascular uptake ( } \leq \text { mediastinal uptake) } \\
\text { Level 1: vascular uptake < hepatic uptake } \\
\text { Level 2: vascular uptake = hepatic uptake; PET test is probably positive } \\
\text { Level 3: vascular uptake > hepatic uptake; PET test is positive }\end{array}$ \\
\hline Visual PMR evaluation (only for GCA) & $\begin{array}{l}\text { Level 0: no FDG uptake } \\
\text { Level 1: uptake < hepatic uptake } \\
\text { Level 2: uptake = hepatic uptake } \\
\text { Level 3: uptake > hepatic uptake } \\
\text { Increased metabolic activity: shoulder and pelvic girth; bursas and } \\
\text { capsules of knee joint; interspinal spaces of cervical and lumbar spine; } \\
\text { ischial and trochanteric bursas }\end{array}$ \\
\hline$(\mathrm{PET}) / \mathrm{CT}(\mathrm{A})$ & $\begin{array}{l}\text { Thickness of vessel wall }(\mathrm{mm}) \\
\text { Contrast enhancement } \\
\text { Present stenosis/aneurism }\end{array}$ \\
\hline \multicolumn{2}{|c|}{ Only for trials } \\
\hline Semi-quantitative PET analysis & Using EANM criteria for SUV [44] \\
\hline Target & Mean SUV(max) of vascular segment arteries under scrutiny \\
\hline Blood pool & Mean SUV(max) of several venous segments under scrutiny \\
\hline Liver & Hepatic SUV(max), preferably of right lobe \\
\hline \multirow{2}{*}{ FDG target-to-background ratio, TBR) } & Mean SUV(max) arteries / Mean SUV veins \\
\hline & Mean SUV(max) arteries / SUV(max) liver \\
\hline Vascular segments & $\begin{array}{l}\text { Carotid, subclavian, axillary, spinal arteries, ascending aorta, aortic arch, } \\
\text { pulmonary arteries, descending aorta, abdominal aorta }\end{array}$ \\
\hline Joints & $\begin{array}{l}\text { Shoulder and pelvic girth, knee joints, cervical and lumbar spine, ischial } \\
\text { and trochanteric bursas }\end{array}$ \\
\hline
\end{tabular}

Notes: PMR - polymyalgia rheumatica; GCA - giant cell arteritis; FDG - fluorodesoxyglucose; PET - positron emission tomography; CT(A) - computed tomography-angiography; EANM - European Association of Nuclear Medicine; LVV - Iarge-vessel vasculitis; SUV(max) - (maximum) standardized uptake value. 
atherosclerosis-related inflammation; development of new multimodal systems of PET/CT cameras for the improved cranial imaging; use of radioisotopes attached to the PMR and LVV pathogenesis-involved proteins and cells as the PET tracers [42].

\section{Conclusions}

The improvement of PMR-attended vasculitis, aortic pathologies and rheumatic diseases of the elderly patients is one of the topical issues for the medical science and clinical practice. There are a lot of studies and recommendations dealing with this issue directly. It is possible to detect inflammation and degenerative changes of aortic wall as well as complications being developed only by means of imaging techniques.

Most PMR patients require imaging techniques; however, the clinical evaluation remains a key element of diagnostic process, while the clinic-anamnestic method remains a principal tool of differentiation among PMR, tumors and late-onset rheumatic diseases. During the examination, the healthcare provider should measure bilateral arterial blood pressure, perform heart and vessel auscultations, and assess the vascular status of magistral arteries. Upon arising, the clinical LVV suspicion should be followed by imaging tests in order to detect the arterial blood pressure and pulse asymmetry on the patient's limbs, diastolic murmur with aortic regurgitation, vascular bruits, as well as persistent PMR, inflammatory dorsalgia, pelvic pain and leg pains.

Despite a wide variety of imaging tests, there is no optimal option; not one of them is validated for monitoring PMR and LVV course and management. In 2020, it was the FDG-PET/CT method which was approved by two clinician societies - the Italian Society of Reumatology (Società Italiana di Reumatologia, SIR) and the European Headache Federation (EHF). The content-analysis of nuclear medicine societies (EANM/SNMMI/PIG/ASNC, 2018) demonstrated their support of FDG-PET/CT(A) use for diagnostics of the PMR-associated extracranial vessel injuries, despite the evidence base weakness. The benefit of PET and PET/CT in terms of LVV detection is well-grounded. The PET and MSCT angiography's accuracy is better confirmed as individual tests, though a hybrid test is more informative.

The new studies are necessary for the procedure improvement and test value accretion at the stage of primary vasculitis diagnostics, relapse detection and therapy control. The standard of FDG exposure in terms of its duration also requires clarification. In the clinical practice and during the trials, one should take into account the factors affecting the test results and their interpretation, namely atherosclerosis, diabetes, age, body mass index, glycemic level and acute phase markers.

For the clinical practice and trials, the EANM/SNMMI/ PIG/ASNC recommends various criteria of FDG-PET/ $\mathrm{CT}(\mathrm{A})$ evaluation. Besides the imaging qualitative methods, they suggest using the semi-quantitative methods, such as the comparison of FDG uptake by the arterial segments versus hepatic and blood uptake. Their validation requires large prospective studies.
Apart from the standardization of FDG-PET/CT(A) result evaluation, one requires consensus as to the earliest possible performance of test prior to the GC therapy initiation, reimbursement, implementation of newest imaging tools for the cranial vessels and approaches to the radiation loading reduction. In the long run, the standardized PMR and vasculitis management is supplemented by theragnostics.

The multidisciplinary approach to LVV detection and its association with pain syndromes in the elderly patients is evidenced by the EHF guidelines (2020), developed for the neurologists. Among the FDG-PET factors of limitation, they list their high costs and radiation loading, low accessibility and absence of standardization [31].

In terms of radiation loading, one should point out the inadequacy of "effective dose" as a notion for the evaluation of population risk in the epidemiological trials. According to Salvatori M. et al. (2019), the clinical practice requires reduction of radiation loading which should be achieved both in preparation and imaging test performance (namely PET/CT) and the choice of radiopharmaceutical drug, customized calculation of radiation dosage, compliance with referential diagnostic levels and rules of preparation, use of corresponding CT protocols and exposure parameters, adaptation of new technical devices to the new reconstruction algorithms [87].

Conflicts of interests. Authors declare the absence of any conflicts of interests and their own financial interest that might be construed to influence the results or interpretation of their manuscript.

Information on the individual contributions: Puzanova O.H. - concept and design, writing the text and preparing it for publication; Lyzikov A.A. - editing the texts, supplementing the valuable informative content, preparing the text for publication.

\section{References}

1. Bunchuk NV. Revmaticheskie zabolevaniia pozhilykh (izbrannye) [Rheumatic diseases of the elderly (selected)]. Moscow: MEDpress-inform; 2010. 272 p. (in Russian).

2. Mansalis K. Myalgias and Myopathies: Polymyalgia Rheumatica and Giant Cell Arteritis. FP Essent. 2016 Jan;440:16-22.

3. Pioro MH. Primary Care Vasculitis: Polymyalgia Rheumatica and Giant Cell Arteritis. Prim Care. 2018 Jun;45(2):305-323. https://doi.org/10.1016/j. pop.2018.02.007.

4. Matteson EL, Buttgereit F, Dejaco C, Dasgupta B. Glucocorticoids for Management of Polymyalgia Rheumatica and Giant Cell Arteritis. Rheum Dis Clin North Am. 2016 Feb;42(1):75-90, viii. https://doi.org/10.1016/j. rdc.2015.08.009.

5. Hellmich B. Management of polymyalgia rheumatica and large vessel vasculitis. Internist. 2016;57(11):1069-1078. https://doi.org/10.1007/s00108-016-0131-x. (in German).

6. Hamrin B, Jonsson N, Hellsten S. "Polymyalgia arteritica". Further clinical and histopathological studies with a report of six autopsy cases. Ann Rheum Dis. 1968 Sep;27(5):397-405. https://doi.org/10.1136/ard.27.5.397. 
7. Cimmino MA, Camellino D. Large vessel vasculitis: which imaging method? Swiss Med Wkly. 2017 Mar;147:w14405. https://doi.org/10.4414/smw.2017.14405.

8. Smiyan S, Holovach I, Komorovsky R, Kmetyuk Y, Ashykhmin A. Role of PET/CT in the diagnosis of large vessel vasculitis in a patient with systemic inflammatory response syndrome. Eur J Rheumatol. 2014 Dec;1(4):174-175. https:// doi.org/10.5152/eurjrheumatol.2014.140078.

9. Camellino D, Cimmino MA. Imaging of polymyalgia rheumatica: indications on its pathogenesis, diagnosis and prognosis. Rheumatology (Oxford). 2012 Jan;51(1):77-86. https://doi.org/10.1093/rheumatology/keq450.

10. Liozon E, de Boysson H, Dalmay F, et al. Development of Giant Cell Arteritis after Treating Polymyalgia or Peripheral Arthritis: A Retrospective Case-control Study. J Rheumatol. 2018 May;45(5):678-685. https://doi.org/10.3899/ jrheum. 170455.

11. Lensen KD, Voskuyl AE, Comans EF, van der Laken CJ, Smulders YM. Extracranial giant cell arteritis: A narrative review. Neth J Med. 2016 Jun;74(5):182-192.

12. Netiazhenko VZ, Puzanova OG. Giant cell arteritis: epidemiology, diagnosis, prognosis. Bol', sustavy, pozvonočnik. 2019;9(2):90-107. 1507.9.2.2019.172121. (in Russian)

13. Lyzikov AN, Puzanova OG, Lyzikov AA. Giant cell arteritis: proven and debatable aspects of treatment. Bol', sustavy, pozvonočnik. 2020;10(1):17-38. https://doi. org/10.22141/2224-1507.10.1.2020.199720. (in Russian).

14. Niinimaki E, Kajander H, Paavonen T, Sioris T, Mennander A. Aiming at one-stage corrective surgery for extended thoracic aortic dilatation. Int J Angiol. 2014 Jun;23(2):101106. https://doi.org/10.1055/s-0034-1370887.

15. Sato O, Takagi A, Miyata T, Takayama Y. Aortic aneurysm in patients with autoimmune disorders treated with corticosteroids. Eur J Vasc Endovasc Surg. 1995 Oct;10(3):366369. https://doi.org/10.1016/S1078-5884(05)80059-0.

16. Erbel R, Aboyans V, Boileau C, et al. Corrigendum to: 2014 ESC Guidelines on the diagnosis and treatment of aortic diseases. Eur Heart J. 2015 Nov 1;36(41):2779. https:// doi.org/10.1093/eurheartj/ehv178.

17. Kuznechevsky FV, Osipov AK, Evsikov EM, Abramov IS, Otarova SM. Prevalence and clinical features of aorta aneurysm; and dissections: 10-year results of consequent autopsies made at OM Filatov City Clinical Hospital № 15. Russian Journal of Cardiology. 2004;(6):5-13. (in Russian).

18. Robson JC, Kiran A, Maskell J, et al. The relative risk of aortic aneurysm in patients with giant cell arteritis compared with the general population of the UK. Ann Rheum Dis. 2015 Jan;74(1):129-135. https://doi.org/10.1136/annrheumdis-2013-204113.

19. National Institute for Health and Care Excellence (NICE). Abdominal aortic aneurysm: diagnosis and management (NG156). London: National Institute for Health and Care Excellence (UK); 2020 Mar 19. 49 p.

20. Stone JR, Bruneval P, Angelini A, et al. Consensus statement on surgical pathology of the aorta from the Society for Cardiovascular Pathology and the Association for European Cardiovascular Pathology: I. Inflammatory diseases.
Cardiovasc Pathol. 2015 Sep-Oct;24(5):267-78. https://doi org/10.1016/j.carpath.2015.05.001.

21. Canadian Task Force on Preventive Health Care. Recommendations on screening for abdominal aortic aneurysm in primary care. CMAJ. 2017 Sep 11;189(36):E1137E1145. https://doi.org/10.1503/cmaj.170118.

22. Kuzmik GA, SangAX, ElefteriadesJA. Natural history of thoracic aortic aneurysms. J Vasc Surg. 2012 Aug;56(2):565571. https://doi.org/10.1016/j.jvs.2012.04.053.

23. Kozlov BN, Panfilov DS, Gutor SS, et al. Morphological state of the aortic wall in ascending aortic aneurysm. Clin Experiment Surg Petrovsky J. 2018;6(4):43-48. https:// doi.org/10.24411/2308-1198-2018-14006. (in Russian).

24. Lariviere D, Benali K, Coustet B, et al. Positron emission tomography and computed tomography angiography for the diagnosis of giant cell arteritis: A real-life prospective study. Medicine (Baltimore). 2016 Jul;95(30):e4146. https:// doi.org/10.1097/md.0000000000004146.

25. Saeyeldin AA, Velasques CA, Mahmood SUB, et al. Thoracic aortic aneurysm: unlocking the «silent killer» secrets. Gen Thorac Cardiovasc Surg. 2019;67(1):1-11. https://doi. org/10.1007/s11748-017-0874-x.

26. Koster MJ, Matteson EL, Warrington KJ. Large-vessel giant cell arteritis: diagnosis, monitoring and management. Rheumatology (Oxford). 2018 Feb 1;57(Suppl_2):ii32-ii42. https://doi.org/10.1093/rheumatology/kex424.

27. Löffler C, Hoffend J, Benck U, Krämer BK, Bergner $\mathrm{R}$. The value of ultrasound in diagnosing extracranial largevessel vasculitis compared to FDG-PET/CT: A retrospective study. Clin Rheumatol. 2017 Sep;36(9):2079-2086. https:// doi.org/10.1007/s10067-017-3669-7.

28. Quinn KA, Grayson PC. The Role of Vascular Imaging to Advance Clinical Care and Research in Large-Vessel Vasculitis. Curr Treatm Opt Rheumatol. 2019 Mar;5(1):20-35. https://doi.org/10.1007/s40674-019-00114-0.

29. Villiger PM. Large vessel vasculitis: Giant cell arteritis and Takayasu arteritis. Z Rheumatol. 2017 Aug;76(6):509523. https://doi.org/10.1007/s00393-017-0331-3. (in German).

30. Nielsen BD, Gormsen LC, Hansen IT, Keller KK, Therkildsen P, Hauge EM. Three days of high-dose glucocorticoid treatment attenuates large-vessel 18F-FDG uptake in large-vessel giant cell arteritis but with a limited impact on diagnostic accuracy. Eur J Nucl Med Mol Imaging. 2018 Jul;45(7):1119-1128. https://doi.org/10.1007/s00259-0184021-4.

31. Mollan SP, Paemeleire K, Versijpt J, Luqmani R, Sinclair AJ. European Headache Federation recommendations for neurologists managing giant cell arteritis. J Headache Pain. 2020 Mar 17;21(1):28. https://doi.org/10.1186/s10194020-01093-7.

32. Dasgupta B, Cimmino MA, Maradit-Kremers H, et al. 2012 provisional classification criteria for polymyalgia rheumatica: a European League Against Rheumatism/American College of Rheumatology collaborative initiative. Ann Rheum Dis. 2012 Apr;71(4):484-492. https://doi.org/10.1136/annrheumdis-2011-200329.

33. Dejaco C, Singh YP, Perel P, et al. 2015 Recommendations for the management of polymyalgia rheumatica: a 
European League Against Rheumatism/American College of Rheumatology collaborative initiative. Ann Rheum Dis. 2015 Oct;74(10):1799-1807. https://doi.org/10.1136/annrheumdis-2015-207492.

34. Dejaco C, Ramiro S, Duftner C, et al. EULAR recommendations for the use of imaging in large vessel vasculitis in clinical practice. Ann Rheum Dis. 2018 May;77(5):636643. https://doi.org/10.1136/annrheumdis-2017-212649.

35. Dasgupta B, Borg FA, Hassan N, et al. BSR and BHPR guidelines for the management of giant cell arteritis. Rheumatology (Oxford). 2010 Aug;49(8):1594-1597. https:// doi.org/10.1093/rheumatology/keq039a.

36. Bienvenu B, Ly KH, Lambert M, et al. Management of giant cell arteritis: Recommendations of the French Study Group for Large Vessel Vasculitis (GEFA). Rev Med Interne. 2016 Mar;37(3):154-165. https://doi.org/10.1016/j. revmed.2015.12.015.

37. Mackie SL, Dejaco C, Appenzeller S, et al. British Society for Rheumatology guideline on diagnosis and treatment of giant cell arteritis. Rheumatology (Oxford). 2020 Mar 1;59(3):e1-e23. https://doi.org/10.1093/rheumatology/ kez672.

38. Buttgereit F, Brabant T, Dinges $\mathrm{H}$, et al. $\mathrm{S} 3$ guideline on treatment of polymyalgia rheumatica: evidence based guideline of the German Society of Rheumatology (DGRh), the Austrian Society of Rheumatology and Rehabilitation (ÖGR) and the Swiss Society of Rheumatology (SGR) and participating medical scientific specialist societies and other organizations. Z Rheumatol. 2018 Jun;77(5):429-441. https:// doi.org/10.1007/s00393-018-0476-8. (in German).

39. Ughi N, Sebastiani GD, Gerli R, et al. The Italian Society of Rheumatology clinical practice guidelines for the management of polymyalgia rheumatica. Reumatismo. 2020 Apr 10;72(1):1-15. https://doi.org/10.4081/reumatismo.2020.1268.

40. Schirmer JH, Aries PM, Balzer K, et al. S2k-Leitlinie: Management der Großgefäßvaskulitiden [S2k guidelines: management of large-vessel vasculitis. Z Rheumatol. 2020 Nov;79(Suppl 3):67-95. https://doi.org/10.1007/s00393-02000893-1. (in German).

41. Puzanova OG, Moshkovska YuO, Sobol VO. Polymyalgia rheumatica: concerted efforts of the European rheumatological societies. Bol', sustavy, pozvonočnik. 2020;10(3):118-126. https://doi.org/10.22141/22241507.10.3.2020.212033.

42. Slart RHJA; Writing group; Reviewer group, et al. FDG-PET/CT(A) imaging in large vessel vasculitis and polymyalgia rheumatica: joint procedural recommendation of the EANM, SNMMI, and the PET Interest Group (PIG), and endorsed by the ASNC. Eur J Nucl Med Mol Imaging. 2018 Jul;45(7):1250-1269. https://doi.org/10.1007/s00259-0183973-8.

43. Jamar F, Buscombe J, Chiti A, et al. EANM/ SNMMI guideline for $18 \mathrm{~F}-\mathrm{FDG}$ use in inflammation and infection. J Nucl Med. 2013 Apr;54(4):647-658. https://doi. org/10.2967/jnumed.112.112524.

44. Boellaard R, Delgado-Bolton R, Oyen WJ, et al. FDG PET/CT: EANM procedure guidelines for tumour imaging: version 2.0. Eur J Nucl Med Mol Imaging. 2015
Feb;42(2):328-354. https://doi.org/10.1007/s00259-0142961-x.

45. Dorbala S, Di Carli MF, Delbeke D, et al. SNMMI/ ASNC/SCCT guideline for cardiac SPECT/CT and PET/ CT 1.0. J Nucl Med. 2013 Aug;54(8):1485-1507. https://doi. org/10.2967/jnumed.112.105155.

46. Chareonthaitawee P, Beanlands RS, Chen W, et al. Joint SNMMI-ASNC Expert Consensus Document on the Role of 18F-FDG PET/CT in Cardiac Sarcoid Detection and Therapy Monitoring. J Nucl Med. 2017 Aug;58(8):1341-1353. https://doi.org/10.2967/jnumed.117.196287.

47. Bucerius J, Hyafil F, Verberne HJ, et al. Position paper of the Cardiovascular Committee of the European Association of Nuclear Medicine (EANM) on PET imaging of atherosclerosis. Eur J Nucl Med Mol Imaging. 2016 Apr;43(4):780-792. https://doi.org/10.1007/s00259-015-3259-3.

48. American College of Radiology; North American Society for Cardiovascular Imaging; Society of Interventional Radiology; Society for Pediatric Radiology. ACR-NASCISIR-SPR practice parameter for the performance and interpretation of body computed tomography angiography (CTA). Revised 2016 (Resolution 16). Available from: https://www. acr.org/-/media/ACR/Files/Practice-Parameters/BodyCTA.pdf?la=en. Accessed: October 26, 2017.

49. Hyafil F, Vigne J. Nuclear Imaging: Focus on Vascular Probes. Arterioscler Thromb Vasc Biol. 2019 Jul;39(7):13691378. https://doi.org/10.1161/atvbaha.119.312586.

50. Ernst D, Baerlecken NT, Schmidt RE, Witte T. Large vessel vasculitis and spondyloarthritis: coincidence or associated diseases? Scand J Rheumatol. 2014;43(3):246-248. https:// doi.org/10.3109/03009742.2013.850737.

51. Yamashita H, Kubota K, Takahashi Y, et al. Wholebody fluorodeoxyglucose positron emission tomography/ computed tomography in patients with active polymyalgia rheumatica: evidence for distinctive bursitis and large-vessel vasculitis. Mod Rheumatol. 2012 Sep;22(5):705-711. https:// doi.org/10.1007/s10165-011-0581-x.

52. Kubota K, Yamashita H, Mimori A. Clinical Value of FDG-PET/CT for the Evaluation of Rheumatic Diseases: Rheumatoid Arthritis, Polymyalgia Rheumatica, and Relapsing Polychondritis. Semin Nucl Med. 2017 Jul;47(4):408-424. https://doi.org/10.1053/j.semnuclmed.2017.02.005.

53. Yuge S, Nakatani K, Yoshino K, Koyama T. Diagnosing polymyalgia rheumatica on 18F-FDG PET/CT: typical uptake patterns. Ann Nucl Med. 2018 Oct;32(8):573-577. https://doi.org/10.1007/s12149-018-1269-5.

54. Bakos A, Besenyi Z, Sipka G, et al. 18F-FDG-PET/ $\mathrm{CT}$ in the evaluation and differential diagnosis of active largevessel vasculitis. A prospective study. Orv Hetil. 2020 May 1;161(20):829-838. https://doi.org/10.1556/650.2020.31710. (in Hungarian).

55. Cimmino MA, Camellino D, Paparo F, et al. High frequency of capsular knee involvement in polymyalgia rheumatica/giant cell arteritis patients studied by positron emission tomography. Rheumatology (Oxford). 2013 Oct;52(10):18651872. https://doi.org/10.1093/rheumatology/ket229.

56. Malik D, Verma R, Gupta V, et al. Semiquantitative Interpretation Criteria for Fluorodeoxyglucose-Positron Emission Tomography/Computed Tomography in Large-Vessel Vas- 
culitis: Pattern Recognition and Correlation with Polymyalgia Rheumatica. Indian J Nucl Med. 2020 Jan-Mar;35(1):6-12. https://doi.org/10.4103/ijnm.ijnm_136_19.

57. Lavado-Pérez C, Martínez-Rodríguez I, MartínezAmador N, et al. (18)F-FDG PET/CT for the detection of large vessel vasculitis in patients with polymyalgia rheumatica. Rev Esp Med Nucl Imagen Mol. 2015 Sep-Oct;34(5):275-281. https://doi.org/10.1016/j.remn.2015.05.011.

58. Rehak Z, Vasina J, Nemec P, et al. Various forms of (18)F-FDG PET and PET/CT findings in patients with polymyalgia rheumatica. Biomed Pap Med Fac Univ Palacky Olomouc Czech Repub. 2015 Dec;159(4):629-636. https://doi. org/10.5507/bp.2015.026.

59. Einspieler I, Thürmel K, Pyka T, et al. Imaging large vessel vasculitis with fully integrated PET/MRI: a pilot study. Eur J Nucl Med Mol Imaging. 2015 Jun;42(7):1012-1024. https://doi.org/10.1007/s00259-015-3007-8.

60. De Boysson H, Dumont A, Liozon E, et al. Giant-cell arteritis: concordance study between aortic CT angiography and FDG-PET/CT in detection of large-vessel involvement. Eur J Nucl Med Mol Imaging. 2017 Dec;44(13):2274-2279. https://doi.org/10.1007/s00259-017-3774-5.

61. Einspieler I, Thürmel K, Eiber M. Fully integrated whole-body [18F]-fludeoxyglucose positron emission tomography/magnetic resonance imaging in therapy monitoring of giant cell arteritis. Eur Heart J. 2016 Feb 7;37(6):576. https:// doi.org/10.1093/eurheartj/ehv607.

62. Prieto-Peña D, Martínez-Rodríguez I, Loricera J, et al. Predictors of positive 18F-FDG PET/CT-scan for large vessel vasculitis in patients with persistent polymyalgia rheumatica. Semin Arthritis Rheum. 2019 Feb;48(4):720-727. https://doi.org/10.1016/j.semarthrit.2018.05.007.

63. Bucerius J, Mani V, Moncrieff C, et al. Optimizing 18F-FDG PET/CT imaging of vessel wall inflammation: the impact of $18 \mathrm{~F}-\mathrm{FDG}$ circulation time, injected dose, uptake parameters, and fasting blood glucose levels. Eur J Nucl Med Mol Imaging. 2014 Feb;41(2):369-383. https://doi. org/10.1007/s00259-013-2569-6.

64. Huet P, Burg S, Le Guludec D, Hyafil F, Buvat I. Variability and uncertainty of $18 \mathrm{~F}-\mathrm{FDG}$ PET imaging protocols for assessing inflammation in atherosclerosis: suggestions for improvement. J Nucl Med. 2015 Apr;56(4):552-559. https://doi.org/10.2967/jnumed.114.142596.

65. Rosenblum JS, Quinn KA, Rimland CA, Mehta NN, Ahlman MA, Grayson PC. Clinical Factors Associated with Time-Specific Distribution of 18F-Fluorodeoxyglucose in Large-Vessel Vasculitis. Sci Rep. 2019 Oct 23;9(1):15180. https://doi.org/10.1038/s41598-019-51800-X.

66. Watanabe R, Hilhorst M, Zhang H, et al. Glucose metabolism controls disease-specific signatures of macrophage effector functions. JCI Insight. 2018 Oct 18;3(20):e123047. https://doi.org/10.1172/jci.insight.123047.

67. Lai LYH, Harris E, West RM, Mackie SL. Association between glucocorticoid therapy and incidence of diabetes mellitus in polymyalgia rheumatica and giant cell arteritis: a systematic review and meta-analysis. RMD Open. 2018 Feb 28;4(1):e000521. https://doi.org/10.1136/rmdopen-2017-000521.
68. Halliburton SS, Abbara S, Chen MY, et al. SCCT guidelines on radiation dose and dose-optimization strategies in cardiovascular CT. J Cardiovasc Comput Tomogr. 2011 Jul-Aug;5(4):198-224. https://doi.org/10.1016/j. ject.2011.06.001.

69. Agard C, Barrier JH, Dupas B, et al. Aortic involvement in recent-onset giant cell (temporal) arteritis: a case-control prospective study using helical aortic computed tomodensitometric scan. Arthritis Rheum. 2008 May 15;59(5):670-676. https://doi.org/10.1002/art.23577.

70. Prieto-González S, Arguis P, García-Martínez A, et al. Large vessel involvement in biopsy-proven giant cell arteritis: prospective study in 40 newly diagnosed patients using CT angiography. Ann Rheum Dis. 2012 Jul;71(7):1170-1176. https://doi.org/10.1136/annrheumdis-2011-200865.

71. Prieto-González S, García-Martínez A, Tavera-Bahillo I, et al. Effect of glucocorticoid treatment on computed tomography angiography detected large-vessel inflammation in giant-cell arteritis. A prospective, longitudinal study. Medicine (Baltimore). 2015 Feb;94(5):e486. https://doi.org/10.1097/ md.0000000000000486.

72. Lensen KD, Comans EF, Voskuyl AE, et al. Large-vessel vasculitis: interobserver agreement and diagnostic accuracy of 18F-FDG-PET/CT. Biomed Res Int. 2015;2015:914692. https://doi.org/10.1155/2015/914692.

73. Soussan M, Nicolas P, Schramm C, et al. Management of large-vessel vasculitis with FDG-PET: a systematic literature review and meta-analysis. Medicine (Baltimore). 2015 Apr;94(14):e622. https://doi.org/10.1097/ md.0000000000000622.

74. Rehák Z, Szturz P. Comment on: FDG PET in the early diagnosis of large-vessel vasculitis. Eur J Nucl Med Mol Imaging. 2014 Mar;41(3):579-580. https://doi.org/10.1007/ s00259-013-2662-X.

75. Lehmann P, Buchtala S, Achajew N, et al. 18F-FDG PET as a diagnostic procedure in large vessel vasculitis-a controlled, blinded re-examination of routine PET scans. Clin Rheumatol. 2011 Jan;30(1):37-42. https://doi.org/10.1007/ s10067-010-1598-9.

76. Besson FL, de Boysson H, Parienti JJ, Bouvard G, Bienvenu B, Agostini D. Towards an optimal semiquantitative approach in giant cell arteritis: an (18)F-FDG PET/ CT case-control study. Eur J Nucl Med Mol Imaging. 2014 Jan;41(1):155-166. https://doi.org/10.1007/s00259-0132545-1.

77. Stellingwerff MD, Brouwer E, Lensen KDF, et al. Different Scoring Methods of FDG PET/CT in Giant Cell Arteritis: Need for Standardization. Medicine (Baltimore). 2015 Sep;94(37):e1542. https://doi.org/10.1097/ md.0000000000001542.

78. Bai B, Bading J, Conti PS. Tumor quantification in clinical positron emission tomography. Theranostics. $2013 \mathrm{Oct}$ 7;3(10):787-801. https://doi.org/10.7150/thno.5629.

79. Gholami S, Salavati A, Houshmand S, Werner TJ, Alavi A. Assessment of atherosclerosis in large vessel walls: A comprehensive review of FDG-PET/CT image acquisition protocols and methods for uptake quantification. J Nucl Cardiol. 2015 Jun;22(3):468-479. https://doi.org/10.1007/ s12350-015-0069-8. 
80. Lensen KDF, van Sijl AM, Voskuyl AE, et al. Variability in quantitative analysis of atherosclerotic plaque inflammation using 18F-FDG PET/CT. PLoS One. 2017 Aug 11;12(8):e0181847. https://doi.org/10.1371/journal. pone. 0181847 .

81. Lee YH, Choi SJ, Ji JD, Song GG. Diagnostic accuracy of 18F-FDG PET or PET/CT for large vessel vasculitis : A meta-analysis. Z Rheumatol. 2016 Nov;75(9):924-931. https://doi.org/10.1007/s00393-015-1674-2.

82. Moosig F, Czech N, Mehl C, et al. Correlation between 18-fluorodeoxyglucose accumulation in large vessels and serological markers of inflammation in polymyalgia rheumatica: a quantitative PET study. Ann Rheum Dis. 2004 Jul;63(7):870-873. https://doi.org/10.1136/ ard.2003.011692.

83. Castellani M, Vadrucci M, Florimonte L, Caronni M, Benti R, Bonara P. 18F-FDG uptake in main arterial branches of patients with large vessel vasculitis: visual and semiquantitative analysis. Ann Nucl Med. 2016 Jul;30(6):409420. https://doi.org/10.1007/s12149-016-1075-x.

84. Kitajima K, Suenaga Y, Sugimura K. Present and future role of FDG-PET/CT imaging in the management of head and neck carcinoma. Jpn J Radiol. 2015 Dec;33(12):776789. https://doi.org/10.1007/s11604-015-0495-1.
85. Nielsen BD, Hansen IT, Kramer S, et al. Simple dichotomous assessment of cranial artery inflammation by conventional 18F-FDG PET/CT shows high accuracy for the diagnosis of giant cell arteritis: a case-control study. Eur J Nucl Med Mol Imaging. 2019 Jan;46(1):184-193. https://doi. org/10.1007/s00259-018-4106-0.

86. Sammel AM, Hsiao E, Schembri G, et al. Diagnostic Accuracy of Positron Emission Tomography/Computed Tomography of the Head, Neck, and Chest for Giant Cell Arteritis: A Prospective, Double-Blind, Cross-Sectional Study. Arthritis Rheumatol. 2019 Aug;71(8):1319-1328. https://doi. org/10.1002/art.40864.

87. Salvatori M, Rizzo A, Rovera G, Indovina L, Schillaci O. Radiation dose in nuclear medicine: the hybrid imaging. Radiol Med. 2019 Aug;124(8):768-776. https://doi. org/10.1007/s11547-019-00989-y.

Received 15.01.2021

Revised 08.02.2021

Accepted 17.02.2021

\section{Information about authors}

Olha H. Puzanova, MD, PhD, Associate Professor, Professor at the Department of Internal and Occupational Diseases; Private Higher Educational Institution «Kyiv Medical University»; Kyiv, Ukraine; e-mail:dr.puzanova@kmu.edu.ua; https://orcid.org/0000-0002-4451-659X

Alexei A. Lyzikov, MD, PhD, Professor, Head of the Department of Surgical Diseases 1 with a Course of Cardiovascular Surgery; Educational Institution «Gomel State Medical University»; Gomel, Republic of Belarus; e-mail: alexei_lyzikov@gsmu.by; https://orcid.org/0000-0003-0639-121X.

Пузанова О.Г. ${ }^{1}$, Лизіков О.А. ${ }^{2}$

'ПВНЗ «Київський медичний університет», м. Київ, Україна

гуО «Гомельський державний медичний університет», м. Гомель, Республіка Білорусь

\section{Ревматична поліміалгія у клінічних настановах 2018-2020 pp. Частина II: діагностика васкуліту}

Резюме. Вдосконалення діагностики ревматичних хвороб у літніх людей та хвороб аорти - актуальні завдання медицини. У патогенезі аневризм, розшарувань, розривів аорти значущими є запалення та структурні зміни ії стінки, для виявлення яких застосовують візуалізуючі методи. Веденню ревматичної поліміалгії, гігантоклітинного артеріїту, аневризм аорти присвячено низку міжнародних настанов. 3 аортитом пов'язано до 40 \% випадків ревматичної поліміалгії. Клінічна підозра на нього виникає за виявлення асиметрії артеріального тиску й пульсу, шуму аортальної регургітації, судинних шумів, персистенції ревматичної поліміалгії, запального болю у спині, ділянці тазу, нижніх кінцівках. У 2020 році саме позитронно-емісійна томографія/комп'ютерна томографія схвалені Італійським товариством ревматологів для діагностики васкуліту при ревматичній поліміалгії на етапі вторинної допомоги та Європейською федерацією головного болю для діагностики великосудинного гігантоклітинного артеріїту в неврологічній практиці. Наведено огляд настанови Європейської асоціації ядерної медицини, Товариства ядерної медицини і молекулярної візуалізації та Американського товариства ядерної кардіології шодо використання позитронно-емісійної томографії з фтордеоксиглюкозою в поєднанні 3 комп'ютерною томографією (ангіографією) при васкулітах великих судин і ревматичній поліміалгії (2018). Її співставлено 3 клінічними настановами, іншими настановами товариств ядерної медицини й новими науковими даними. Описано процедуру дослідження та підготовку до неї. Розглянуто критерії оцінки васкуліту, запропоновані для клінічної практики та клінічних досліджень, а також чинники, що впливають на результати тесту та їх інтерпретацію (атеросклероз, діабет, вік, індекс маси тіла, рівні глікемії та маркерів гострої фази). У настанові обгрунтовано користь застосування позитронно-емісійної томографії та пї поєднання з комп'ютерною томографією для виявлення екстракраніального васкуліту, а також цінність комп'ютерної томографії-ангіографії на різних стадіях хвороби. Слід зміцнити доказову базу стандарту часу експозиції фтордеоксиглюкози та користі поєднання позитронно-емісійної томографії з комп'ютерною томографією-ангіографією, зокрема для виявлення рецидивів васкуліту та моніторингу терапії. Необхідні консенсус шодо раннього виконання тесту, стандартизація оцінок його результатів, забезпечення реімбурсації, впровадження нових методик візуалізації судин черепа. У перспективі доказовий підхід до ведення васкуліту доповнить терагностика.

Ключові слова: ревматична поліміалгія; гігантоклітинний артеріїт; аортит; візуалізуюча діагностика; стандарти; огляд 
Пузанова О.Г. ${ }^{1}$, Лызиков А.А. ${ }^{2}$

ЧЧВУЗ “Киевский медицинский университет», г. Киев, Украина

2УО «Гомельский государственный медицинский университет», г. Гомель, Республика Беларусь

\section{Ревматическая полимиалгия \\ в клинических рекомендациях 2018-2020 гr. Часть II: диагностика васкулита}

Резюме. Совершенствование диагностики ревматических болезней пожилых людей и заболеваний аорты - актуальные задачи медицины. В патогенезе аневризм, расслоений, разрывов аорты важна роль воспаления и структурных изменений ее стенки, которые выявляют с помощью визуализирующих методов. Ведению ревматической полимиалгии, гигантоклеточного артериита, аневризм аорты посвящен ряд международных рекомендаций. С аортитом сопряжено до 40 \% случаев ревматической полимиалгии. Клиническое подозрение на него основано на выявлении асимметрии артериального давления и пульса, шума аортальной регургитации, сосудистых шумов, персистенции ревматической полимиалгии, воспалительной боли в спине, области таза и нижних конечностях. В 2020 году именно позитронно-эмиссионная томография/компьютерная томография рекомендована Итальянским обществом ревматологов для диагностики васкулита при ревматической полимиалгии во вторичном звене и Европейской федерацией головной боли для диагностики крупнососудистого гигантоклеточного артериита в неврологической практике. Приведен обзор рекомендаций Европейской ассоциации ядерной медицины, Общества ядерной медицины и молекулярной визуализации и Американского общества ядерной кардиологии по применению позитронно-эмиссионной томографии с фтордеоксиглюкозой в сочетании с компьютерной томографией (ангиографией) при васкулитах крупных сосу- дов и ревматической полимиалгии (2018). Они сопоставлены с клиническими руководствами, другими рекомендациями обществ ядерной медицины и новыми научными данными. Описана процедура исследования и подготовка к нему. Рассмотрены критерии оценки васкулита, предложенные для клинической практики и для клинических исследований, а также факторы, влияющие на результаты теста и их интерпретацию (атеросклероз, диабет, возраст, индекс массы тела, уровни гликемии и маркеров острой фазы). В рекомендациях обоснована польза применения позитронноэмиссионной томографии и ее сочетания с компьютерной томографией для выявления экстракраниального васкулита и ценность компьютерной томографии-ангиографии на разных стадиях болезни. Требует усиления доказательная база стандарта времени экспозиции фтордеоксиглюкозы и пользы сочетания позитронной эмиссионной томографии с компьютерной томографией-ангиографией, в том числе для выявления рецидивов васкулита и мониторинга терапии. Необходим консенсус по раннему выполнению исследования, стандартизация оценок его результатов, обеспечение реимбурсации, внедрение новых методик визуализации сосудов черепа. В перспективе доказательный подход к ведению васкулита дополнит терагностика.

Ключевые слова: ревматическая полимиалгия; гигантоклеточный артериит; аортит; визуализирующая диагностика; стандарты; обзор 